Article

\title{
Novel Conformationally Constrained Analogues of Agomelatine as New Melatoninergic Ligands
}

\author{
Marouan Rami ${ }^{1,2, *}$, Elodie Landagaray ${ }^{1,2}$, Mohamed Ettaoussi ${ }^{1,2}$, Koussayla Boukhalfa ${ }^{1,2}$, \\ Daniel-Henri Caignard ${ }^{3}$, Philippe Delagrange ${ }^{3}$, Pascal Berthelot ${ }^{1,2}$ and Saïd Yous ${ }^{1,2}$ \\ 1 University of Lille Nord de France, F-59000 Lille, France \\ 2 UDSL, EA GRIIOT, UFR Pharmacie, F-59000 Lille, France \\ 3 Département des Sciences Expérimentales, Institut de Recherches Servier, 92150 Suresnes, France \\ * Author to whom correspondence should be addressed; E-Mail: marouanr@yahoo.fr; \\ Tel.: +33-3-2096-4255; Fax: +33-3-2096-4913.
}

Received: 29 October 2012; in revised form: 14 December 2012 / Accepted: 18 December 2012 / Published: 24 December 2012

\begin{abstract}
Novel conformationally restricted analogues of agomelatine were synthesized and pharmacologically evaluated at $\mathrm{MT}_{1}$ and $\mathrm{MT}_{2}$ melatoninergic receptors. Replacement of the $N$-acetyl side chain of agomelatine by oxathiadiazole-2-oxide (compound 3 ), oxadiazole-5(4H)-one (compound 4), tetrazole (compound 5), oxazolidinone (compound 7a), pyrrolidinone (compound 7b), imidazolidinedione (compound 12), thiazole (compounds 13 and 14) and isoxazole moieties (compound 15) led to a decrease of the melatoninergic binding affinities, particularly at $\mathrm{MT}_{1}$. Compounds $\mathbf{7 a}$ and $\mathbf{7 b}$ exhibiting nanomolar affinity towards the $\mathrm{MT}_{2}$ receptors subtypes have shown the most interesting pharmacological results of this series with the appearance of a weak $\mathrm{MT}_{2}$-selectivity.
\end{abstract}

Keywords: agomelatine; agonist; conformationally restriction; melatonin

\section{Introduction}

Melatonin or $\mathrm{N}$-acetyl-5-methoxytryptamine (Figure 1), is a neurohormone that is synthesized and secreted from the pineal gland during the period of darkness following a circadian rhythm [1]. Since the demonstration of its role in many physiological processes such as the regulation of immune functions [2], retinal physiology [3], circadian and seasonal rhythms [4] research efforts to identify new melatoninergic 
ligands grow up continuously. However, much more efforts must be done to clarify the various functions exerted by melatonin and its mechanisms of action.

This neurohormone exerts its multiple pharmacological actions through two G-protein-coupled receptors $\mathrm{MT}_{1}$ and $\mathrm{MT}_{2}$ which were cloned in the mid-1990s [2-5]. A third melatonin binding site, $M T_{3}$, having lower affinity than $\mathrm{MT}_{1}$ and $\mathrm{MT}_{2}$ has been characterized as the hamster homologue of quinone reductase 2 (QR2 EC 1.6.99.2) [6]. Exploring the exact physiological role of each of these binding sites requires selective $\mathrm{MT}_{1}, \mathrm{MT}_{2}$ and $M T_{3}$ ligands. Melatoninergic $\mathrm{MT}_{1}$ receptors are expressed in several areas of the brain in particular in the suprachiasmatic nuclei $(\mathrm{SCN})$ and the pars tuberalis. The $\mathrm{MT}_{2}$ receptors are localized in the SCN and retina. The low affinity binding site, $M T_{3}$ is closely related to the detoxifying enzyme quinone reductase 2 and its exact biological relevance in melatonin's effects is still uncertain [7]. Nonetheless, $M T_{3}$ has shown to be involved in acute inflammatory responses in the rat [8] and in the regulation of intraocular pressure in the rabbit [9].

Figure 1. Chemical structures of melatonin, agomelatine and ramelteon.

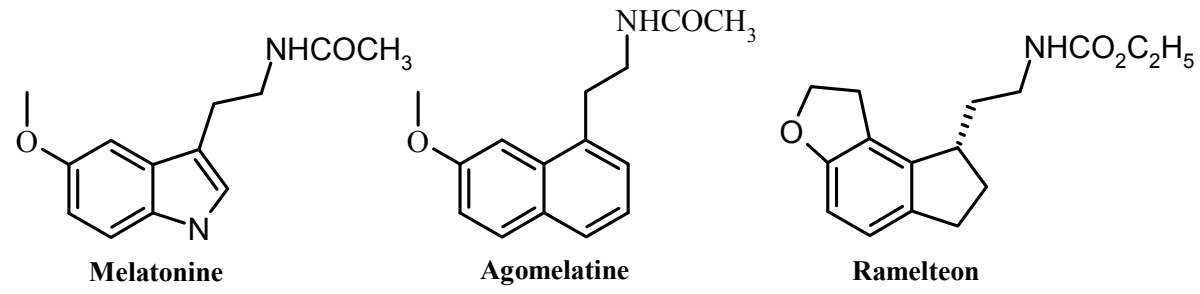

In fact and in order to clarify $\mathrm{MT}_{1}, \mathrm{MT}_{2}$ and $M T_{3}$ biological functions, over the last years several ligands were synthesized [10-19]. Only ramelteon $\left(\right.$ Rozerem $\left.^{\circledR}\right)$ [20] and agomelatine (Valdoxan ${ }^{\circledR}$ ) [21], two $\mathrm{MT}_{1}$ and $\mathrm{MT}_{2}$ receptor agonists, are respectively marketed for the treatment of insomnia and major depressive disorders. Agomelatine is the first antidepressant which does not block the reuptake of monoamines. Therefore it might represent the prototype of a new class of antidepressant drugs. The development of new derivatives is of importance in order to increase efficacy and reduce side effects. Agomelatine, which is also a $5-\mathrm{HT}_{2 \mathrm{C}}$ selective antagonist was revealed to be also potent in resynchronization of circadian rhythms [22,23].

The importance of melatonin as a promising therapeutic target has led to the investigation of the pharmacophoric requirements for its receptors' binding and activation in order to develop selective ligands. Early SAR studies showed that both methoxy group and the $\mathrm{N}$-acetylamino side chain of melatonin are crucial for high receptor affinity and that the relative spatial distance between these groups is also an important factor [24]. In addition, 3D-QSAR analysis of melatoninergic ligands revealed that $\mathrm{MT}_{1}$ and $\mathrm{MT}_{2}$ binding affinity could be enhanced by replacement and/or conformationally restriction of the amide substituent [25]. This approach could help probing the existing pharmacophore for potent $\mathrm{MT}_{1}$ and $\mathrm{MT}_{2}$ selective ligands, and open new therapeutic perspectives by targeting a specific receptor.

In our continuing efforts to develop new melatonin ligands using the agomelatine as a lead, we previousely reported the design and synthesis of melatoninergic $\mathrm{MT}_{1}$ [26,27], $\mathrm{MT}_{2}$ [28-31] and $M T_{3}$-selective ligands [32-34]. We also were the pioneers in preparing non-selective $\mathrm{MT}_{1}$ and $\mathrm{MT}_{2}$ ligands with $5-\mathrm{HT}_{2 \mathrm{C}}$ activity [17]. In this paper we describe the synthesis and pharmacological evaluation of a novel small series of naphtalenic constrained compounds issued from the incorporation of the amide side chain into heterocycles. 


\section{Results and Discussion}

\subsection{Chemistry}

The target compounds 3 and 4 were prepared from 2-(7-methoxynaphth-1-yl)acetonitrile [35]. Compound 3 was obtained via a two steps reaction sequence: (1) treatment with hydroxylamine hydrochloride and sodium methoxide in DMSO to afford the amidoxime $\mathbf{1}$ in accordance with a literature procedure [36]; (2) cyclization with thionyl chloride according to Scheme 1. Compound 2, which was obtained from amidoxime $\mathbf{1}$ by reaction with ethyl chloroformate, was cyclized by treatment with potassium carbonate to provide oxadiazolone 4 [37].

Scheme 1. Synthesis of compounds 3 and 4.

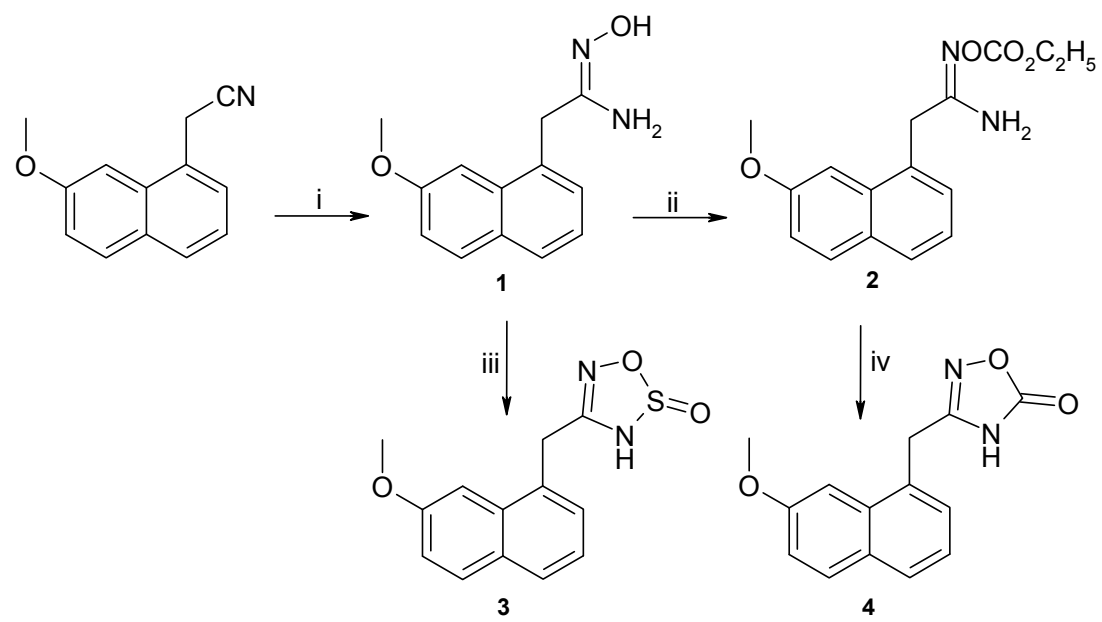

Reagents and conditions: (i) $\mathrm{NH}_{2} \mathrm{OH} . \mathrm{HCl}, \mathrm{NaOMe}, \mathrm{MeOH} / \mathrm{DMSO}, 80^{\circ} \mathrm{C}$; (ii) $\mathrm{ClCO}_{2} \mathrm{Et}, \mathrm{NEt}_{3}, \mathrm{THF}$, reflux; (iii) $\mathrm{SOCl}_{2}$, pyridine, $\mathrm{CH}_{2} \mathrm{Cl}_{2}, 0^{\circ} \mathrm{C}$; (iv) $\mathrm{K}_{2} \mathrm{CO}_{3}$, DMF, $60{ }^{\circ} \mathrm{C}$.

Scheme 2 illustrates the synthetic route to naphthalenic compounds 5-9. Treatment of 2-(7-methoxynaphth-1-yl)acetonitrile with sodium azide in the presence of tributyltin chloride in DMF gave the desired tetrazole 5 [38]. $N$-acetylated derivatives $\mathbf{6 a}, \mathbf{b}$ were derived from 2-(7-methoxynaphth-1-yl)acetonitrile by reduction of the nitrile group and reaction with the appropriate acyl chloride. Carbamate $6 \mathbf{a}$ was then cyclized by heating in an alkaline solution $(\mathrm{NaOH})$ to afford the desired oxazolidinone 7a [39]. Compounds $\mathbf{6 b}$ and $7 \mathbf{b}$ were synthesized as previously described by us [40]. The agomelatine 8 was converted to cyclic $9 \mathbf{a}$ and $\mathbf{9 b}$ by heating in a large excess of DMSO [41].

Finally, synthesis of compounds $\mathbf{1 2 - 1 5}$ was carried out as illustrated in Scheme 3. 2-(7-methoxynaphth-1-yl)acetaldehyde (11) was obtained from (7-methoxynaphth-1-yl)acetic acid [21] via esterification followed by reduction and Dess Martin oxidation [42]. Compound 11 was then converted to the desired imidazolidine-dione $\mathbf{1 2}$ by treatment with potassium cyanide and ammonium carbonate. Compounds 13-15 were prepared under the same conditions by condensation of $\mathbf{1 1}$ with the appropriate heterocyclic amine, followed by reduction of the imine generated in situ by use of sodium cyanoborohydride in the presence of zinc iodide. 
Scheme 2. Synthesis of compounds $7 \mathbf{a}, \mathbf{b}$ and $\mathbf{9 a}, \mathbf{b}$.<smiles>COc1ccc2cccc(Cc3nnn[nH]3)c2c1</smiles><smiles>C=IC</smiles><smiles>COc1ccc2cccc(CC#N)c2c1</smiles><smiles>C1=C[CH-]1</smiles><smiles>COc1ccc2cccc(CCNC(C)=O)c2c1</smiles><smiles></smiles>

$\begin{aligned} 7 \mathrm{a} x & =0 \\ 7 \mathrm{~b} x & =\mathrm{CH}\end{aligned}$

$\uparrow$<smiles>[X]C(=O)NCCc1cccc2ccc(OC)cc12</smiles>

6b X $=\mathrm{CH}_{2}$<smiles>COc1ccc2ccc3c(c2c1)CCN(C(C)=O)C3</smiles>

Reagents and conditions: (i) $\mathrm{Bu}_{3} \mathrm{SnCl}, \mathrm{NaN}_{3}, \mathrm{DMF}, 130{ }^{\circ} \mathrm{C}$; (ii) a) $\mathrm{H}_{2}$, Raney nickel, EtOH, $\mathrm{NH}_{3}$ (gas), 50 bars, $60{ }^{\circ} \mathrm{C}$; b) $\mathrm{ClCO}_{2}\left(\mathrm{CH}_{2}\right)_{2} \mathrm{Cl}$ or $\mathrm{ClCO}\left(\mathrm{CH}_{2}\right)_{3} \mathrm{Cl}$, NEt 3 , THF, rt; (iii) $20 \% \mathrm{NaOH}$, THF, reflux; (iv) $\mathrm{H}_{2}$, Raney nickel, $\left(\mathrm{CH}_{3} \mathrm{CO}\right)_{2} \mathrm{O}, 50$ bars, $60{ }^{\circ} \mathrm{C}, 4 \mathrm{~h}$; (v) DMSO, reflux.

Scheme 3. Synthesis of compounds 12-15.<smiles>COc1ccc2cccc(CC(=O)O)c2c1</smiles><smiles>COc1ccc2cccc(CCO)c2c1</smiles><smiles>COc1ccc2cccc(CC3NC(=O)NC3=O)c2c1</smiles><smiles>CC#CCC=O</smiles><smiles>COc1ccc2cccc(CCNc3cc(C)on3)c2c1</smiles><smiles>COc1ccc2cccc(CCNc3nccs3)c2c1</smiles>

13<smiles>COc1ccc2cccc(CCNc3ncc(C)s3)c2c1</smiles>

Reagents and conditions: (i) $\mathrm{SOCl}_{2}, \mathrm{MeOH}, 0{ }^{\circ} \mathrm{C}$ then $\mathrm{LiAlH}_{4}, \mathrm{Et}_{2} \mathrm{O}$, rt; (ii) Dess-Martin Periodinane, $\mathrm{CH}_{2} \mathrm{Cl}_{2}$, rt; (iii) $\mathrm{KCN}$, $\left(\mathrm{NH}_{4}\right)_{2} \mathrm{CO}_{3}, \mathrm{EtOH} / \mathrm{H}_{2} \mathrm{O}$, reflux; (iv) 2-amino-1,3-thiazole, $\mathrm{NaBH}_{3} \mathrm{CN} / \mathrm{ZnI}_{2}$, $\mathrm{MeOH}$, rt then $\mathrm{HCl}$ (gas)/Et $\mathrm{Et}_{2} \mathrm{O}$; (v) 2-amino-5-methyl-1,3-thiazole, $\mathrm{NaBH}_{3} \mathrm{CN} / \mathrm{ZnI}_{2}, \mathrm{MeOH}$, rt; (vi) 3-amino-5-methyl-1,2-isoxazole, $\mathrm{NaBH}_{3} \mathrm{CN} / \mathrm{ZnI}_{2}, \mathrm{MeOH}$, rt then $\mathrm{HCl}$ (gas)/ $/ \mathrm{Et}_{2} \mathrm{O}$. 


\subsection{Pharmacology}

\subsubsection{Reagents and Chemicals}

2-[ $\left.{ }^{125} \mathrm{I}\right]$ Iodomelatonin $(2200 \mathrm{Ci} / \mathrm{mmol})$ was purchased from NEN (Boston, MA, USA). Other drugs and chemicals were purchased from Sigma-Aldrich (Saint Quentin, France).

\subsubsection{Assays for $M_{1}$ and $M_{2}$ Receptor Subtypes}

$2-\left[{ }^{125} \mathrm{I}\right]$ Iodomelatonin binding assay conditions were essentially as previously described [43]. Briefly, binding was initiated by addition of membrane preparations from transfected CHO cells stably expressing the human melatonin $\mathrm{MT}_{1}$ or $\mathrm{MT}_{2}$ diluted in binding buffer $(50 \mathrm{mM}$ Tris- $\mathrm{HCl}$ buffer, $\mathrm{pH} 7.4$, containing $5 \mathrm{mM} \mathrm{MgCl}_{2}$ ) to 2-[ $\left.{ }^{125} \mathrm{I}\right]$ iodomelatonin (20 $\mathrm{pM}$ for $\mathrm{MT}_{1}$ and $\mathrm{MT}_{2}$ receptors expressed in $\mathrm{CHO}$ cells) and the tested drug. Non-specific binding was defined in the presence of $1 \mu \mathrm{M}$ melatonin. After $120 \mathrm{~min}$ incubation at $37^{\circ} \mathrm{C}$, reaction was stopped by rapid filtration through $\mathrm{GF} / \mathrm{B}$ filters presoaked in $0.5 \%(\mathrm{v} / \mathrm{v})$ polyethylenimine. Filters were washed three times with $1 \mathrm{~mL}$ of ice-cold $50 \mathrm{mM}$ Tris- $\mathrm{HCl}$ buffer, $\mathrm{pH}$ 7.4. Data from the dose-response curves (seven concentrations in duplicate) were analysed using the program PRISM (Graph Pad Software Inc., San Diego, CA, USA) to yield $\mathrm{IC}_{50}$ (inhibitory concentration 50). Results are expressed as $\mathrm{pK}_{\mathrm{i}}\left(\mathrm{pK}_{\mathrm{i}}=-\log 10\left(\mathrm{~K}_{\mathrm{i}}\right)\right)$ with $\mathrm{K}_{\mathrm{i}}=\mathrm{IC}_{50} / 1+([\mathrm{L}] / \mathrm{KD})$, where $[\mathrm{L}]$ is the concentration of radioligand used in the assay and $\mathrm{KD}$, the dissociation constant of the radioligand characterizing the membrane preparation.

\subsection{Discussion}

Conformationally restricted ligands for melatonin receptors were synthesized and their binding affinities at human $\mathrm{MT}_{1}$ and $\mathrm{MT}_{2}$ receptors were determined. The data summarized in Table 1 emphasized the lack of good affinities for the $\mathrm{MT}_{1}$ and $\mathrm{MT}_{2}$ receptors of the prepared compounds. In fact, in comparison with agomelatine the lock of the ethylamido side chain conformation by its incorporation in rigid structures led to the decrease of the binding affinities at both receptors. This decrease of the melatoninergic binding affinities is more noticeable for the $\mathrm{MT}_{1}$ than the $\mathrm{MT}_{2}$ leading to the appearance of a weak $\mathrm{MT}_{2}$-selectivity. Only compounds $\mathbf{7 a}$ and $\mathbf{7 b}$ showed an interesting pharmacological profile by conserving a good binding affinity $\left(10^{-8} \mathrm{M}\right)$ at $\mathrm{MT}_{2}$ receptors subtypes.

Table 1. $\mathrm{MT}_{1}$ and $\mathrm{MT}_{2}$ binding affinities of naphtalenic cyclized compounds.

\begin{tabular}{cccc}
\hline Compound & $\begin{array}{c}\text { Ki (nM) } \\
\mathbf{M T}_{\mathbf{1}}\end{array}$ & $\begin{array}{c}\mathbf{K i}(\mathbf{n M}) \\
\mathbf{M T}_{\mathbf{2}}\end{array}$ & $\begin{array}{c}\mathbf{S} \\
\left.\mathbf{( M T}_{\mathbf{1}} / \mathbf{M T}_{\mathbf{2}}\right)\end{array}$ \\
\hline Melatonin & $0.2 \pm 0.02$ & $0.3 \pm 0.03$ & 0.17 \\
\hline Agomelatine & $0.1 \pm 0.01$ & $0.12 \pm 0.02$ & 0.83 \\
\hline $\mathbf{3}$ & $>1,000$ & 1300 & $>0.77$ \\
\hline $\mathbf{4}$ & $80.0 \pm 16.0$ & $25.2 \pm 10.7$ & 3 \\
\hline $\mathbf{5}$ & $380 \pm 114$ & $190 \pm 84$ & 2 \\
\hline $\mathbf{7 a}$ & $113 \pm 18$ & $6.0 \pm 0.2$ & 19 \\
\hline $\mathbf{7 b}$ & $68.5 \pm 18.2$ & $2.1 \pm 0.01$ & 33 \\
\hline
\end{tabular}


Table 1. Cont.

\begin{tabular}{cccc}
\hline Compound & $\begin{array}{c}\text { Ki (nM) } \\
\mathbf{M T}_{\mathbf{1}}\end{array}$ & $\begin{array}{c}\text { Ki (nM) } \\
\mathbf{M T}_{\mathbf{2}}\end{array}$ & $\begin{array}{c}\mathbf{S} \\
\left.\mathbf{( M T}_{\mathbf{1}} \mathbf{M T}_{\mathbf{2}}\right)\end{array}$ \\
\hline $\mathbf{9 a}$ & $2500 \pm 57$ & $469 \pm 44$ & 5.4 \\
\hline $\mathbf{9 b}$ & $3000 \pm 27$ & $800 \pm 59$ & 3.75 \\
\hline $\mathbf{1 2}$ & $2170 \pm 63$ & $141 \pm 31$ & 15.4 \\
\hline $\mathbf{1 3}$ & $33.9 \pm 8.1$ & $12.5 \pm 0.4$ & 3 \\
\hline $\mathbf{1 4}$ & $389 \pm 121$ & $354 \pm 32$ & 1 \\
\hline $\mathbf{1 5}$ & $48.4 \pm 11.2$ & $20.3 \pm 3.9$ & 2 \\
\hline
\end{tabular}

\section{Experimental}

\subsection{General}

All common reagents and solvents were obtained from commercial sources (Sigma-Aldrich Alfa Aesar or Acros Organics) and used without further purification. Compounds were purified on a glass column using Merck Silica Gel 60 (230-400 mesh). Their purity and mass spectra were determined on a Surveyor MSQ Thermoelectron spectrometer (+cAPCI corona sid $=30.00$, det $=1400.00$ Full ms [100.00-1000.00]). Melting points were determined with a büchi 510 capillary apparatus and are uncorrected. ${ }^{1} \mathrm{H}-\mathrm{NMR}$ spectra were recorded on a Bruker $\mathrm{AC} 300 \mathrm{P}$ spectrometer using $(\mathrm{Me})_{4} \mathrm{Si}$ as internal standard and with DMSO- $d_{6}$ or $\mathrm{CDCl}_{3}$ as solvents; The chemical shifts are reported in ppm (parts per million) $\delta$ and constant $(J)$ values are given in Hertz $(\mathrm{Hz})$. Signal multiplicities are represented by: s (singlet), d (doublet), dd (doublet of doublets), $\mathrm{t}$ (triplet), dt (doublet of triplet), q (quartet) and $\mathrm{m}$ (multiplet). Infrared spectra were obtained on a Perkin-Elmer FT-IR S1000 in KBr pellets. Elemental analyses for final compounds were performed by CNRS Laboratory (Vernaison, France).

2-(7-Methoxynaphth-1-yl)acetamidoxime (1). A mixture of 2-(7-methoxynaphth-1-yl)acetonitrile (5 g, $25.3 \mathrm{mmol})$ and hydroxylamine hydrochloride $(3.52 \mathrm{~g}, 50.6 \mathrm{mmol})$ in DMSO $(20 \mathrm{~mL})$ was treated with $25 \% \mathrm{NaOMe}$ solution in methanol $(11.5 \mathrm{~mL}, 50.6 \mathrm{mmol})$ and heated at $80^{\circ} \mathrm{C}$ for $5 \mathrm{~h}$. After cooling, the solvent was evaporated under reduced pressure. The crude was taken with water, the white solid obtained was washed with water and recrystallized from toluene to afford $3.8 \mathrm{~g}(65 \%$ yield) of $\mathbf{1}$ as a white solid, mp: $151-153{ }^{\circ} \mathrm{C} .{ }^{1} \mathrm{H}-\mathrm{NMR}\left(300 \mathrm{MHz}, \mathrm{DMSO}-d_{6}\right) \delta: 3.71(\mathrm{~s}, 2 \mathrm{H}), 3.88(\mathrm{~s}, 3 \mathrm{H}), 5.38(\mathrm{~s}, 2 \mathrm{H})$, $7.17(\mathrm{dd}, J=8.9,2.2 \mathrm{~Hz}, 1 \mathrm{H}), 7.27(\mathrm{t}, J=7.6 \mathrm{~Hz}, 1 \mathrm{H}), 7.44(\mathrm{~d}, J=7.6 \mathrm{~Hz}, 1 \mathrm{H}), 7.72(\mathrm{~d}, J=7.6 \mathrm{~Hz}, 1 \mathrm{H})$, $7.60(\mathrm{~d}, J=2.2 \mathrm{~Hz}, 1 \mathrm{H}), 7.82(\mathrm{~d}, J=8.9 \mathrm{~Hz}, 1 \mathrm{H}), 8.96(\mathrm{~s}, 1 \mathrm{H}) . \mathrm{IR}\left(\mathrm{cm}^{-1}\right) 1660(\mathrm{C}=\mathrm{N}), 3360,3460(\mathrm{NH})$, 3100-3400 (OH). MS (EI): $m / z=231[\mathrm{M}+\mathrm{H}]^{+}$.

$N$-[(Ethoxycarbonyl)oxy]-2-(7-methoxynaphth-1-yl)acetamidoxime (2). Ethyl chloroformate (0.84 $\mathrm{mL}$, $8.8 \mathrm{mmol}$ ) was added dropwise to a suspension of 1 ( $2 \mathrm{~g}, 8.7 \mathrm{mmol})$ and triethylamine $(2.4 \mathrm{~mL}, 17.4 \mathrm{mmol})$ in $25 \mathrm{~mL}$ of THF. Stirring was maintained for $3 \mathrm{~h}$ at ambient temperature. The reaction mixture was then filtered and the filtrate was evaporated under reduced pressure. The crude was purified by column chromatography $\left(\mathrm{SiO}_{2}\right.$, acetone/toluene/cyclohexane: $\left.2 / 3 / 5\right)$ to give $2.3 \mathrm{~g}(88 \%$ yield $)$ of 2 as a pink solid, mp: $104-106{ }^{\circ} \mathrm{C} .{ }^{1} \mathrm{H}-\mathrm{NMR}\left(300 \mathrm{MHz}, \mathrm{DMSO}-d_{6}\right.$ at $\left.50{ }^{\circ} \mathrm{C}\right) \delta: 1.22(\mathrm{t}, J=7.1 \mathrm{~Hz}, 3 \mathrm{H}), 3.82(\mathrm{~s}, 2 \mathrm{H})$, 
$3.91(\mathrm{~s}, 3 \mathrm{H}), 4.14(\mathrm{q}, J=7.1 \mathrm{~Hz}, 2 \mathrm{H}), 6.13(\mathrm{~s}, 2 \mathrm{H}), 7.16(\mathrm{dd}, J=9.1,2.5 \mathrm{~Hz}, 1 \mathrm{H}), 7.28(\mathrm{t}, J=7.6 \mathrm{~Hz}, 1 \mathrm{H})$, $7.51(\mathrm{~d}, J=7.6 \mathrm{~Hz}, 1 \mathrm{H}), 7.73(\mathrm{~d}, J=7.6 \mathrm{~Hz}, 1 \mathrm{H}), 7.64(\mathrm{~d}, J=2.5 \mathrm{~Hz}, 1 \mathrm{H}), 7.81(\mathrm{~d}, J=9.1 \mathrm{~Hz}, 1 \mathrm{H})$. IR $\left(\mathrm{cm}^{-1}\right) 1680(\mathrm{C}=\mathrm{N}), 1730(\mathrm{C}=\mathrm{O}), 3340,3460(\mathrm{NH}) . \mathrm{MS}(\mathrm{EI}): \mathrm{m} / z=303[\mathrm{M}+\mathrm{H}]^{+}$.

4-[(7-Methoxynaphth-1-yl)methyl]-3H-1,2,3,5-oxathiadiazole 2-oxide (3). Thionyl chloride (0.5 mL, $6.7 \mathrm{mmol})$ in methylene chloride $(2 \mathrm{~mL})$ was added dropwise to a mixture of $\mathbf{1}(1.4 \mathrm{~g}, 6.1 \mathrm{mmol})$ in methylene chloride $(20 \mathrm{~mL})$ and pyridine $(1 \mathrm{~mL}, 12.2 \mathrm{mmol})$ at $0{ }^{\circ} \mathrm{C}$. After stirring for $3 \mathrm{~h}$ at room temperature, the reaction mixture was poured into water and extracted with ethyl acetate. The organic layer was dried over $\mathrm{MgSO}_{4}$, filtered and concentrated under reduced pressure. The residue was recrystallized from cyclohexane/toluene and ethyl ether/petroleum ether to afford $791 \mathrm{mg}$ (47\% yield) of 4 as a white solid, mp: $121-123{ }^{\circ} \mathrm{C}$ (decomp.). ${ }^{1} \mathrm{H}-\mathrm{NMR}\left(300 \mathrm{MHz}, \mathrm{DMSO}-d_{6}\right) \delta: 3.88(\mathrm{~s}, 3 \mathrm{H}), 4.36$ (d, $J=16.3 \mathrm{~Hz}, 1 \mathrm{H}), 4.42(\mathrm{~d}, J=16.3 \mathrm{~Hz}, 1 \mathrm{H}), 7.21(\mathrm{dd}, J=8.9,2.3 \mathrm{~Hz}, 1 \mathrm{H}), 7.29-7.49$ (m, 3H), 7.78-7.94 $(\mathrm{m}, 2 \mathrm{H}), 11.40(\mathrm{~s}, 1 \mathrm{H}) . \mathrm{IR}\left(\mathrm{cm}^{-1}\right) 1620(\mathrm{C}=\mathrm{N}), 3300(\mathrm{NH})$. MS (EI): $m / z=277[\mathrm{M}+\mathrm{H}]^{+}$. Anal. Calcd for $\mathrm{C}_{13} \mathrm{H}_{12} \mathrm{~N}_{2} \mathrm{O}_{3} \mathrm{~S}$ : C, 56.51\%; H, 4.38\%; N, 10.14\%. Found: C, 56.55\%; H, 4.43\%, N, 10.15\%.

3-[(7-Methoxynaphth-1-yl)methyl]-1,2,4-oxadiazole-5(4H)-one (4). Potassium carbonate (1.1 g, $8 \mathrm{mmol})$ was added to a solution of $2(1.2 \mathrm{~g}, 4 \mathrm{mmol})$ in DMF $(10 \mathrm{~mL})$. After $5 \mathrm{~h}$ of stirring at $60{ }^{\circ} \mathrm{C}$, the reaction mixture was poured into water and extracted twice with ethyl acetate. The aqueous phase was acidified with a $3 \mathrm{M} \mathrm{HCl}$ solution and extracted with ethyl acetate. The combined organic phases were washed with water and brine, dried $\left(\mathrm{MgSO}_{4}\right)$, filtered, and concentrated under reduce pressure. The residue was recrystallized from toluene to give $712 \mathrm{mg}$ of $\mathbf{3}$ (yield 70\%) as a white solid, mp: $185-187^{\circ} \mathrm{C}$ (decomp.). ${ }^{1} \mathrm{H}-\mathrm{NMR}\left(300 \mathrm{MHz}, \mathrm{DMSO}-d_{6}\right) \delta: 3.89(\mathrm{~s}, 3 \mathrm{H}), 4.33(\mathrm{~m}, 2 \mathrm{H}), 7.23(\mathrm{dd}, J=8.6,2.5 \mathrm{~Hz}, 1 \mathrm{H}), 7.34$ (t, $J=7.40 \mathrm{~Hz}, 1 \mathrm{H}), 7.39$ (d, $J=2.50 \mathrm{~Hz}, 1 \mathrm{H}), 7.44(\mathrm{~d}, J=7.40 \mathrm{~Hz}, 1 \mathrm{H}), 7.83(\mathrm{~d}, J=7.40 \mathrm{~Hz}, 1 \mathrm{H}), 7.89$ (d, $J=8.6 \mathrm{~Hz}, 1 \mathrm{H}), 11.40(\mathrm{~s}, 1 \mathrm{H})$. IR $\left(\mathrm{cm}^{-1}\right) 1725(\mathrm{C}=\mathrm{N}), 3440(\mathrm{NH})$. MS (EI): $m / z=257[\mathrm{M}+\mathrm{H}]^{+}$. Anal. Calcd for $\mathrm{C}_{14} \mathrm{H}_{12} \mathrm{~N}_{2} \mathrm{O}_{3}$ : C, 65.61\%; H, 4.72\%; N, 10.93\%. Found: C, 65.64\%; H, 4.76\%; N, 10.90\%.

5-(7-Methoxynaphth-1-yl methyl)-1H-tetrazole (5). A mixture of 2-(7-methoxynapht-1-yl)acetonitrile ( $2 \mathrm{~g}, 1.01 \mathrm{mmol})$, sodium azide $(2.62 \mathrm{~g}, 40.4 \mathrm{mmol})$ and tributyltin chloride $(10.9 \mathrm{~mL}, 40.4 \mathrm{mmol})$ in dry DMF $(20 \mathrm{~mL})$ was heated to reflux and monitored by TLC until the reaction was complete $(\sim 7 \mathrm{~h})$. After being cooled to room temperature, $1 \mathrm{M} \mathrm{HCl}(50 \mathrm{~mL})$ was added to precipitate the crude product. The white solid product was collected, washed with water and ether, and dried with phosphorous pentoxide under vacuum and recrystallized from cyclohexane affording $1.21 \mathrm{~g}(50 \%$ yield $)$ of tetrazole 5 as a beige solid, mp: $177-179{ }^{\circ} \mathrm{C}$ (decomposition). ${ }^{1} \mathrm{H}-\mathrm{NMR}$ (300 MHz, DMSO- $\left.d_{6}+\mathrm{D}_{2} \mathrm{O}\right) \delta: 3.88(\mathrm{~s}, 3 \mathrm{H}), 4.74$ (s, 2H), $7.22(\mathrm{dd}, J=9.1, J=2.3 \mathrm{~Hz}, 1 \mathrm{H}), 7.31-7.47(\mathrm{~m}, 3 \mathrm{H}), 7.83(\mathrm{~d}, J=7.6 \mathrm{~Hz}, 1 \mathrm{H}), 7.90(\mathrm{~d}, J=9.1 \mathrm{~Hz}$, $1 \mathrm{H}), 7.81(\mathrm{~d}, J=9.1 \mathrm{~Hz}, 1 \mathrm{H}) . \mathrm{MS}(\mathrm{EI}): m / z=241[\mathrm{M}+\mathrm{H}]^{+}$.

$\mathrm{N}$-(2-Chloroethyl)oxycarbonyl)-2-(7-methoxynaphth-1-yl)ethylamine (6a). 2-Chloroethyl chloroformate $(0.87 \mathrm{~mL}, 8.41 \mathrm{mmol})$ and triethylamine $(1.2 \mathrm{~mL}, 8.41 \mathrm{mmol})$ were added to a solution of 2-(7-methoxynaphth-1-yl)ethylamine hydrochloride $(2 \mathrm{~g}, 8.41 \mathrm{mmol})$ in THF $(30 \mathrm{~mL})$. The reaction mixture was stirred at room temperature for $36 \mathrm{~h}$. After filtration, the filtrate was concentrated under vacuum and purified by column chromatography $\left(\mathrm{SiO}_{2}\right)$ using cyclohexane/ethyl acetate; $8 / 2$ as eluant to gave $1.7 \mathrm{~g}$ (65\% yield) of carbamate $6 \mathbf{a}$ as a white solid, mp: $73-75^{\circ} \mathrm{C} .{ }^{1} \mathrm{H}-\mathrm{NMR}\left(300 \mathrm{MHz}\right.$, DMSO- $\left.d_{6}\right)$ $\delta$ : 3.04-3.34 (m, 4H), 3.80 (t, $J=5.2 \mathrm{~Hz}, 2 \mathrm{H}), 3.94$ (s, 3H), 4.24 (t, $J=5.2 \mathrm{~Hz}, 2 \mathrm{H}), 7.18$ (dd, $J=9.1$, 
$2.1 \mathrm{~Hz}, 1 \mathrm{H}), 7.22-7.42(\mathrm{~m}, 2 \mathrm{H}), 7.53(\mathrm{~d}, J=2.1 \mathrm{~Hz}, 1 \mathrm{H}), 7.60(\mathrm{t}, J=5.4 \mathrm{~Hz}, 1 \mathrm{H}), 7.72(\mathrm{~d}, J=7.9 \mathrm{~Hz}$, $1 \mathrm{H}), 7.84(\mathrm{~d}, J=9.1 \mathrm{~Hz}, 1 \mathrm{H}) . \mathrm{MS}(\mathrm{EI}): m / z=[\mathrm{M}+\mathrm{H}]^{+}$.

$N$-[(2-(7-methoxynaphth-1-yl)]-1,3-oxazolidin-2-one (7a). A mixture of carbamate $6 \mathbf{6 a}(1.2 \mathrm{~g}, 3.9 \mathrm{mmol})$ and $20 \% \mathrm{NaOH}(3 \mathrm{~mL}, 15 \mathrm{mmol})$ in THF $(20 \mathrm{~mL})$ were refluxed for $39 \mathrm{~h}$. The residue was evaporated to dryness, water was added, and the mixture was stirred and extracted with ethyl acetate. The combined organic phases were washed with water $(50 \mathrm{~mL})$, dried $\left(\mathrm{MgSO}_{4}\right)$, filtered and concentrated under vacuum. The residue was purified by column chromatography $\left(\mathrm{SiO}_{2}\right.$, cyclohexane/ethyl acetate, 6/4) to afford $868 \mathrm{mg}\left(82 \%\right.$ yield) of $7 \mathbf{a}$ as a white solid, $\mathrm{mp} 78-80{ }^{\circ} \mathrm{C} .{ }^{1} \mathrm{H}-\mathrm{NMR}$ (300 MHz, DMSO- $\left.d_{6}\right) \delta: 3.24$ $(\mathrm{m}, 2 \mathrm{H}), 3.47(\mathrm{~m}, 2 \mathrm{H}), 3.56(\mathrm{t}, J=8.28 \mathrm{~Hz}, 2 \mathrm{H}), 3.92(\mathrm{~s}, 3 \mathrm{H}), 4.22(\mathrm{t}, J=8.37 \mathrm{~Hz}, 2 \mathrm{H}), 7.17(\mathrm{dd}$, $J=8.97,2.40 \mathrm{~Hz}, 1 \mathrm{H}), 7.30(\mathrm{~m}, 1 \mathrm{H}), 7.36(\mathrm{~d}, J=6.48 \mathrm{~Hz}, 1 \mathrm{H}), 7.46(\mathrm{~d}, J=2.41 \mathrm{~Hz}, 1 \mathrm{H}) ; 7.72(\mathrm{~d}$, $J=8.00 \mathrm{~Hz}, 1 \mathrm{H}), 7.83(\mathrm{~d}, J=8.97 \mathrm{~Hz}, 1 \mathrm{H}) . \mathrm{MS}(\mathrm{EI}): m / z=272[\mathrm{M}+\mathrm{H}]^{+}$.

\subsection{General Protocol for the Preparation of Compounds $\mathbf{9 a}$ and $\mathbf{9 b}$}

A solution of agomelatine (4 g, $16.4 \mathrm{mmol})$ in DMSO $(100 \mathrm{~mL})$ was refluxed for $15 \mathrm{~h}$. The reaction mixture was poured into ice and extracted twice with ether, organic phase was washed with water and brine and then concentrated under reduced pression. The crude was purified by column chromatography $\left(\mathrm{SiO}_{2}\right)$ using ether as eluant.

1-(10-Methoxy-1,2,3,4-tetrahydro-naphto[1,8-cd]azepin-2-yl)ethanone (9a). Recrystallized from isopropyl ether to furnish $1.59 \mathrm{~g}$ (38\% yield) as a white solid, mp: $107-108{ }^{\circ} \mathrm{C} .{ }^{1} \mathrm{H}-\mathrm{NMR}(300 \mathrm{MHz}$, $75^{\circ} \mathrm{C}$, DMSO- $\left.d_{6}\right) \delta: 1.88(\mathrm{~s}, 3 \mathrm{H}), 3.44(\mathrm{t}, J=6.3 \mathrm{~Hz}, 2 \mathrm{H}), 3.81$ and $3.87(\mathrm{t}, \mathrm{t}, 2 \mathrm{H}), 3.93$ and $3.97(\mathrm{~s}, \mathrm{~s}$, $3 \mathrm{H}), 5.11$ and $5.20(\mathrm{~s}, \mathrm{~s}, 2 \mathrm{H}), 7.21-7.30(\mathrm{~m}, 2 \mathrm{H}), 7.34$ and $7.41(\mathrm{~d}, \mathrm{~d}, J=9.2 \mathrm{~Hz}, 1 \mathrm{H}), 7.69-7.73(\mathrm{~m}, 1 \mathrm{H})$, 7.77 and $7.83(\mathrm{~d}, \mathrm{~d}, J=9.2 \mathrm{~Hz}, 1 \mathrm{H})$. IR $\left(\mathrm{cm}^{-1}\right) 1625(\mathrm{C}=\mathrm{O})$. MS (EI) $\mathrm{m} / z=256[\mathrm{M}+\mathrm{H}]^{+}$. Anal. Calcd for $\mathrm{C}_{16} \mathrm{H}_{17} \mathrm{NO}_{2}$ : C, 75.27\%; H, 6.71\%; N, 5.49\%. Found: C, 75.25\%; H, 6.72\%; N, 5.48\%.

1-(9-Methoxy-1,2,3,4-tetrahydro-benzo[f]isoquinolein-3-yl)ethanone (9b). Recrystallized from isopropyl ether, 9b was obtained with $2 \%$ yield as a white solid, mp: $141-143{ }^{\circ} \mathrm{C} .{ }^{1} \mathrm{H}-\mathrm{NMR}(300 \mathrm{MHz}$, $\left.60{ }^{\circ} \mathrm{C}, \mathrm{DMSO}-d_{6}\right) \delta: 2.14(\mathrm{~s}, 3 \mathrm{H}), 3.10(\mathrm{~m}, 2 \mathrm{H}), 3.84(\mathrm{t}, J=6.0 \mathrm{~Hz}, 2 \mathrm{H}), 3.92(\mathrm{~s}, 3 \mathrm{H}), 4.75(\mathrm{~s}, 2 \mathrm{H}), 7.16$ $(\mathrm{m}, J=8.3 \mathrm{~Hz}, 1 \mathrm{H}), 7.17(\mathrm{dd}, J=8.8 \mathrm{~Hz}, 1 \mathrm{H}), 7.27(\mathrm{~m}, 1 \mathrm{H}), 7.69(\mathrm{~d}, J=8.3 \mathrm{~Hz}, 1 \mathrm{H}), 7.81(\mathrm{~d}, J=8.8 \mathrm{~Hz}$, 1H). IR $\left(\mathrm{cm}^{-1}\right) 1620$ (CO). MS (EI): $m / z=256[\mathrm{M}+\mathrm{H}]^{+}$. Anal. Calcd for $\mathrm{C}_{16} \mathrm{H}_{17} \mathrm{NO}_{2}: \mathrm{C}, 75.27 \%$; $\mathrm{H}$, 6.71\%; N, 5.49\%. Found: C, 75.29\%; H, 6.72\%; N, 5.45\%.

2-(7-Methoxynaphth-1-yl)ethanol (10). Thionyl chloride $(27 \mathrm{~mL}, 370 \mathrm{mmol})$ was added dropwise to a solution of (7-methoxynaphth-1-yl) acetic acid (20 g, $92.5 \mathrm{mmol})$ in methanol $(350 \mathrm{~mL})$ at $0{ }^{\circ} \mathrm{C}$. After stirring for $5 \mathrm{~h}$, the reaction mixture was evaporated under reduced pressure. The residue was dissolved in ethyl acetate and washed with $10 \%$ aqueous potassium carbonate solution and water. The organic layer was dried over $\mathrm{MgSO}_{4}$, filtered and concentrated under reduced pressure affording the intermediate ester. The residue was dissolved in ether $(100 \mathrm{~mL})$ and added dropwise to a suspension of lithium aluminium hydride $(12.4 \mathrm{~g}, 327 \mathrm{mmol})$ in ether $(200 \mathrm{~mL})$ at $0{ }^{\circ} \mathrm{C}$. The stirring was maintained at room temperature for $4 \mathrm{~h}$. Water $(50 \mathrm{~mL})$ and $20 \% \mathrm{NaOH}$ aqueous solution $(12 \mathrm{~mL})$ were added and the mixture was stirred and filtered. After evaporation under reduced pressure, the residue was recrystallized 
from cyclohexane to furnish $13.7 \mathrm{~g}$ (73\% yield) of alcohol 10 as a white solid, mp: $79-81{ }^{\circ} \mathrm{C} .{ }^{1} \mathrm{H}-\mathrm{NMR}$ (300 MHz, $\left.\mathrm{CDCl}_{3}+\mathrm{D}_{2} \mathrm{O}\right) \delta: 3.30(\mathrm{t}, J=6.69 \mathrm{~Hz}, 2 \mathrm{H}), 3.94(\mathrm{~s}, 3 \mathrm{H}), 3.99$ (t, $\left.J=6.75,2 \mathrm{H}\right), 7.17$ (dd, $J=9.2,2.3 \mathrm{~Hz}, 1 \mathrm{H}), 7.24-7.38(\mathrm{~m}, 3 \mathrm{H}), 7.68(\mathrm{~d}, J=8.1 \mathrm{~Hz}, 1 \mathrm{H}), 7.77(\mathrm{~d}, J=9.2 \mathrm{~Hz}, 1 \mathrm{H}) . \mathrm{IR}\left(\mathrm{cm}^{-1}\right)$ 3000-3330 (OH). MS (EI): $m / z=203[\mathrm{M}+\mathrm{H}]^{+}$.

2-(7-Methoxynaphth-1-yl)acetaldehyde (11). To a stirred solution of alcohol 10 (6 g, $29.6 \mathrm{mmol})$ in anhydrous $\mathrm{CH}_{2} \mathrm{Cl}_{2}(300 \mathrm{~mL})$ under argon atmosphere was added Dess-Martin periodinane (25 g, $59.2 \mathrm{mmol}$ ) and stirred at room temperature for $5 \mathrm{~h}$. The reaction mixture was quenched by adding saturated $\mathrm{Na}_{2} \mathrm{~S}_{2} \mathrm{O}_{4}(60 \mathrm{~mL})$ and saturated $\mathrm{NaHCO}_{3}(8 \mathrm{~mL})$. The heterogeneous mixture was extracted with $\mathrm{CH}_{2} \mathrm{Cl}_{2}$ and the organic layer was washed with saturated $\mathrm{NaHCO}_{3}$ and water. The combined organic layers were dried over $\mathrm{MgSO}_{4}$ and the solvent removed under reduced pressure. The residue was purified by column chromatography $\left(\mathrm{SiO}_{2}, \mathrm{CH}_{2} \mathrm{Cl}_{2}\right)$ to give $5.2 \mathrm{~g}$ (87\% yield) of $\mathbf{1 1}$ as a yellow oil. ${ }^{1} \mathrm{H}-\mathrm{NMR}\left(300 \mathrm{MHz}, \mathrm{CDCl}_{3}+\mathrm{D}_{2} \mathrm{O}\right) \delta: 3.91(\mathrm{~s}, 3 \mathrm{H}), 4.03(\mathrm{~d}, J=2.3 \mathrm{~Hz}, 2 \mathrm{H}), 7.08-7.87(\mathrm{~m}, 6 \mathrm{H}), 9.73$ (t, $J=2.3 \mathrm{~Hz}, 1 \mathrm{H}) . \mathrm{IR}\left(\mathrm{cm}^{-1}\right) 1700(\mathrm{C}=\mathrm{O})$. MS (EI): $m / z=201[\mathrm{M}+\mathrm{H}]^{+}$.

5-[(7-Methoxynaphth-1-yl)methyl]-imidazolidin-2,4-diones (12). Ammonium carbonate (1.67 g, $17.4 \mathrm{mmol})$ and potassium cyanide (341 mg, $5.24 \mathrm{mmol}$ ) were added to a stirred solution of aldehyde 14 (700 mg, $3.49 \mathrm{mmol})$ in $20 \mathrm{~mL}(16 \mathrm{~mL} / 4 \mathrm{~mL})$ of ethanol/water, the mixture was refluxed overnight. After cooling, the reaction mixture was poured into cold water. The resulting precipitate was filtrated, washed with water and recrystallized from isopropyl ether affording $400 \mathrm{mg}$ (42\% yield) of $\mathbf{1 5}$ as a white solid, mp: 236-238 ${ }^{\circ} \mathrm{C}$ (decomp.). ${ }^{1} \mathrm{H}-\mathrm{NMR}\left(300 \mathrm{MHz}, \mathrm{DMSO}-d_{6}\right) \delta: 3.26(\mathrm{~m}, 2 \mathrm{H}), 3.92(\mathrm{~s}, 3 \mathrm{H}), 4.44(\mathrm{~m}, 1 \mathrm{H})$, 7.06-7.97 (m, 7H), 10.56 (s, 1H). IR ( $\left.\mathrm{cm}^{-1}\right)$ 1680, $1750(\mathrm{C}=\mathrm{O}), 3270(\mathrm{NH}) . \mathrm{MS}(\mathrm{EI}): \mathrm{m} / z=271[\mathrm{M}+\mathrm{H}]^{+}$. Anal. Calcd for $\mathrm{C}_{15} \mathrm{H}_{14} \mathrm{~N}_{2} \mathrm{O}_{3}$ : C, 66.65\%; H, 5.22\%; N, 10.36\%. Found: C, 65.68\%; H, 5.25\%, N, 10.38\%.

\subsection{General Protocol for the Preparation of Compounds 13-15}

To a mixture of compound $\mathbf{1 1}(0.5 \mathrm{~g}, 2.49 \mathrm{mmol})$ and the appropriate heterocyclic amine (10 mmol) in methanol $(20 \mathrm{~mL})$ and $0.2 \mathrm{~mL}$ of DMF, were added a solution of sodium cyanoborohydride (172 $\mathrm{mg}$, $2.73 \mathrm{mmol})$ and zinc iodide $(437 \mathrm{mg}, 1.36 \mathrm{mmol})$ in methanol $(5 \mathrm{~mL})$. The reaction was stirred at room temperature for $5 \mathrm{~h}$ and concentrated under reduced pressure to dryness, hydrolyzed and extracted with ethyl acetate. The organic layer was dried $\left(\mathrm{MgSO}_{4}\right)$, filtered, and concentrated under reduced pressure.

2-[2-(7-Methoxynaphth-1-yl)]-ethylamino]-1,3-thiazole hydrochloride (13). The crude was purified by column chromatography $\left(\mathrm{SiO}_{2}\right)$ using cyclohexane/ethyl acetate; $7 / 3$ as eluant, treatment with gaseous $\mathrm{HCl}$ in ether provided $280 \mathrm{mg}$ (35\% yield) of hydrochloride salt 13 as a white solid, mp: $156-158{ }^{\circ} \mathrm{C}$. ${ }^{1} \mathrm{H}-\mathrm{NMR}\left(300 \mathrm{MHz}, \mathrm{DMSO}-d_{6}\right) \delta: 3.38(\mathrm{t}, J=7.1 \mathrm{~Hz}, 2 \mathrm{H}), 3.81(\mathrm{~m}, 2 \mathrm{H}), 3.93(\mathrm{~s}, 3 \mathrm{H}), 6.92(\mathrm{~d}, J=4.3 \mathrm{~Hz}$, $1 \mathrm{H}), 7.19(\mathrm{dd}, J=9.0,2.4 \mathrm{~Hz}, 1 \mathrm{H}), 7.25-7.49(\mathrm{~m}, 4 \mathrm{H}), 7.75(\mathrm{~m}, 2 \mathrm{H}), 10.22(\mathrm{~s}, 1 \mathrm{H}) . \mathrm{IR}\left(\mathrm{cm}^{-1}\right)$ 2500-3160 (N $\left.{ }^{+} \mathrm{H}\right)$. MS (EI): $m / z=285[\mathrm{M}+\mathrm{H}]^{+}$. Anal. Calcd for $\mathrm{C}_{16} \mathrm{H}_{17} \mathrm{ClN}_{2} \mathrm{OS}: \mathrm{C}, 59.90 \% ; \mathrm{H}, 5.34 \%$; N, 8.73\%. Found: C, 59.94\%; H, 5.32\%, N, 8.75\%.

2-[2-(7-Methoxynaphth-1-yl)ethylamino]-5-methyl-1,3-thiazole (14). Recrystallized from cyclohexane to furnish $364 \mathrm{mg}$ (46\% yield) of 14 as a white solid, mp: $150-152{ }^{\circ} \mathrm{C}$ (decomp.). ${ }^{1} \mathrm{H}-\mathrm{NMR}$ (300 MHz, DMSO- $\left.d_{6}+\mathrm{D}_{2} \mathrm{O}\right) \delta: 2.22(\mathrm{~s}, 3 \mathrm{H}), 3.28(\mathrm{t}, J=7.5 \mathrm{~Hz}, 2 \mathrm{H}), 3.47(\mathrm{~m}, 2 \mathrm{H}), 3.95(\mathrm{~s}, 3 \mathrm{H}), 6.71(\mathrm{~s}, 1 \mathrm{H})$, 
7.11-7.89 (m, 6H). IR (cm $\left.{ }^{-1}\right) 3170(\mathrm{NH}) . \mathrm{MS}(\mathrm{EI}): \mathrm{m} / z=299[\mathrm{M}+\mathrm{H}]^{+}$. Anal. Calcd for $\mathrm{C}_{17} \mathrm{H}_{18} \mathrm{~N}_{2} \mathrm{OS}: \mathrm{C}$, $68.43 \%$; H, 6.08\%; N, 9.39\%. Found: C, 68.39\%; H, 6.13\%, N, 9.36\%.

3-[2-(7-Methoxynaphth-1-yl)ethylamino]-5-methyl-1,2-isoxazole hydrochloride (15). Recrystallized from cyclohexane to afford $333 \mathrm{mg}$ (42\% yield) of 15 as a white solid, mp $144-146{ }^{\circ} \mathrm{C}$ (decomp.). ${ }^{1} \mathrm{H}-\mathrm{NMR}\left(300 \mathrm{MHz}, \mathrm{DMSO}-d_{6}+\mathrm{D}_{2} \mathrm{O}\right) \delta: 2.24(\mathrm{~s}, 3 \mathrm{H}), 3.18-3.39(\mathrm{~m}, 4 \mathrm{H}), 3.93(\mathrm{~s}, 3 \mathrm{H}), 5.67(\mathrm{~s}, 1 \mathrm{H})$, $7.15(\mathrm{dd}, J=9.1,2.1 \mathrm{~Hz}, 1 \mathrm{H}), 7.21-7.39(\mathrm{~m}, 2 \mathrm{H}), 7.65(\mathrm{~d}, J=2.1 \mathrm{~Hz}, 1 \mathrm{H}), 7.69$ (d, $J=8.0 \mathrm{~Hz}, 1 \mathrm{H}), 7.81$ $(\mathrm{d}, J=9.1 \mathrm{~Hz}, 1 \mathrm{H}) . \mathrm{IR}\left(\mathrm{cm}^{-1}\right) 2200-3000\left(\mathrm{~N}^{+} \mathrm{H}\right)$. MS (EI): $\mathrm{m} / z=283[\mathrm{M}+\mathrm{H}]^{+}$. Anal. Calcd for $\mathrm{C}_{17} \mathrm{H}_{19} \mathrm{Cl}$ $\mathrm{N}_{2} \mathrm{O}_{2}$ : C, 64.05\%; H, 6.01\%; N, 8.79\%. Found: C, 64.07\%; H, 6.04\%, N, 8.76\%.

\section{Conclusions}

In the search for pharmacological tools for the elucidation of $\mathrm{MT}_{1}$ and $\mathrm{MT}_{2}$ biological functions, we synthesized and pharmacologically evaluated a new series of constrained naphthalenic compounds. Indeed, replacement of the $N$-acetyl side chain of agomelatine by oxathiadiazole-2-oxide, oxadiazole-5(4H)-one, oxazolidinone, 2-oxopyrrolidine, imidazolidin-2,4-dione, thiazole, 5-methyl-1,3-thiazole, or 5-methyl-1,2-isoxazole hydrochloride resulted in a decrease of the melatoninergic binding affinities particularly towards the $\mathrm{MT}_{1}$ receptors leading to the appearance of a weak $\mathrm{MT}_{2}$-selectivity. Compound $\mathbf{7 b}$ conserves good affinity for both melatonin receptors subtypes and exhibited a selectivity of about 33 -fold for the $\mathrm{MT}_{2}$ receptor subtype.

\section{Acknowledgments}

This research was supported by the Laboratoires Servier. We are grateful to the Région Nord-Pas de Calais (France), the Ministère de la Jeunesse, de l'Education Nationale et de la Recherche (MJENR, France) and the Fonds Européens de Développement Régional (FEDER) for the funding for the $300 \mathrm{MHz}$ NMR facilities.

\section{References}

1. Lerner, A.B.; Case, J.D.; Heinzelman, R.V. Structure of melatonin. J. Am. Chem. Soc. 1959, 81, 6084-6085.

2. Guerrero, J.M.; Reiter, R.J. Melatonin-Immune System Relationships. Curr. Top. Med. Chem. 2002, 2, 167-169.

3. Dubocovich, M.L.; Mansana, M.I.; Benloucif, S. Molecular pharmacology and function of melatonin receptor subtype. Adv. Exp. Med. Biol. 1999, 460, 181-190.

4. Malpaux, B.; Migaud, M.; Tricoire, H.; Chemineau, P. Biology of Mammalian Photoperiodism and the Critical Role of the Pineal Gland and Melatonin. J. Biol. Rhythms. 2001, 16, 336-347.

5. Reiter, R.J. The melatonin rhythm: Both a clock and a calendar. Experientia 1993, 49, 654-664.

6. Nosjean, O.; Ferro, M.; Coge, F.; Beauverger, P.; Henlin, J.M.; Lefoulon, F.; Fauchere, J.L.; Delagrange, P.; Canet, E.; Boutin, J.A. $\mathrm{MT}_{1}$ melatonin receptors mediate somatic, behavioral, and reproductive neuroendocrine responses to photoperiod and melatonin in Siberian hamsters. J. Biol. Chem. 2000, 275, 31311-31317. 
7. Vella, F.; Ferry, G.; Delagrange, P.; Boutin, J.A.; NRH: Quinone reductase 2: An enzyme of surprises and mysteries. Biochem. Pharmacol. 2005, 71, 1-12.

8. Lotufo, C.M.C.; Lopes, C.; Dubocovich, M.L.; Farsky, S.H.P.; Markus, R.P. Melatonin and $\mathrm{N}$-acetylserotonin inhibit leukocyte rolling and adhesion to rat microcirculation. Eur. J. Pharmacol. 2001, 430, 351-357.

9. Pintor, J.; Martin, L.; Pelaez, T.; Hoyle, C.H.V.; Peral, A. Involvement of melatonin $M T_{3}$ receptors in the regulation of intraocular pressure in rabbits. Eur. J. Pharmacol. 2001, 416, 251-254.

10. Zlotos, D.P. Recent Advances in Melatonin Receptor Ligands. Arch. Pharm. Chem. Life Sci. 2005, $338,229-247$.

11. Garratt, P.J.; Tsotinis, A. Synthesis of compounds as melatonin agonists and antagonists. Mini-Rev. Med. Chem. 2007, 7, 1075-1088.

12. Carocci, A.; Catalano, A.; Lovece, A.; Lentini, G.; Duranti, A.; Lucini, V.; Pannacci, M.; Scaglione, F.; Franchini, C. Design, synthesis, and pharmacological effects of structurally simple ligands for $\mathrm{MT}_{1}$ and $\mathrm{MT}_{2}$ melatonin receptors. Bioorg. Med. Chem. 2010, 18, 6496-6511.

13. Tsotinis, A.; Afroudakis, P.A.; Davidson, K.; Prashar, A.; Sugden, D. Design, Synthesis, and Melatoninergic Activity of New Azido- and Isothiocyanato-Substituted Indoles. J. Med. Chem. 2007, 50, 6436-6440.

14. Nonno, R.; Pannacci, M.; Lucini, V.; Angeloni, D.; Fraschini, F.; Stankov, B.M. Ligand efficacy and potency at recombinant human $\mathrm{MT}_{2}$ melatonin receptors: Evidence for agonist activity of some $\mathrm{MT}_{1}$-antagonists. Br. J. Pharmacol. 1999, 127, 1288-1294.

15. Fisher, S.P.; Sugden, D. Sleep-promoting action of IIK7, a selective $\mathrm{MT}_{2}$ melatonin receptor agonist in the rat. Neurosci. Lett. 2009, 457, 93-96.

16. Koike, T.; Hoashi, Y.; Takai, T.; Nakayama, M.; Yukuhiro, N.; Ishikawa, T.; Hirai, K.; Uchikawa, O. 1,6-Dihydro- $2 H$-indeno[5,4-b]furan derivatives: Design, synthesis and pharmacological characterization of a novel class of highly potent $\mathrm{MT}_{2}$-selective agonists. J. Med. Chem. 2011, 54, 3436-3444.

17. Ettaoussi, M.; Sabaouni, A.; Rami, M.; Boutin, J.A.; Delagrange, P.; Renard, P.; Spedding, M.; Caignard, D.H.; Berthelot, P.; Yous, S. Design, synthesis and pharmacological evaluation of new series of naphthalenicanalogues as melatoninergic $\left(\mathrm{MT}_{1} / \mathrm{MT}_{2}\right)$ and serotoninergic $5-\mathrm{HT}_{2 \mathrm{C}}$ dual ligands (I). Eur. J. Med. Chem. 2012, 49, 310-323.

18. Markl, C.; Attia, M.I.; Julius, J.; Sethi, S.; Witt-Enderby, P.A.; Zlotos, D.P. Synthesis and pharmacological evaluation of 1,2,3,4-tetrahydropyrazino [1,2-a]indole and 2-[(phenylmethylamino)methyl]-1H-indole analogues as novel melatoninergic ligands. Bioorg. Med. Chem. 2009, $17,4583-4594$.

19. Attia, M.I.; Witt-Enderby, P.A.; Julius, J. Synthesis and pharmacological evaluation of pentacyclic 6a,7-dihydrodiindole and 2,3-dihydrodiindole derivatives as novel melatoninergic ligands. Bioorg. Med. Chem. 2008, 16, 7654-7661.

20. Simpson, D.; Curran, M.P. Ramelteon: A review of its use in Insomnia. Drugs 2008, 68, 1901-1919.

21. Montgomery, S.A. Major depressive disorders: Clinical efficacy and tolerability of agomelatine, a new melatonergicagonist. Eur. Neuropsychopharmacol. 2006, 16, S633-S638. 
22. Dagyte, G.; Trentani, A.; Postema, F.; Luiten, P.G.; Den Boer, J.A.; Gabriel, C.; Mocaër, E.; Meerlo, P.; Van der Zee, E. The novel antidepressant agomelatine normalizes hippocampal neuronal activity and promotes neurogenesis in chronically stressed rats. CNS Neurosci. Ther. 2010, 16, 195-207.

23. Dagyte, G.; Luiten, P.G.; De Jager, T.; Gabriel, C.; Mocaër, E.; Den Boer, J.A.; Van der Zee, E. Chronic stress and antidepressant agomelatine induce region-specific changes in synapsin I expression in the rat brain. J. Neurosci. Res. 2011, 89, 1646-1657.

24. Mathé-Allainmat, M.; Andrieux, J.; Langlois, M. Recent developments in melatonin receptor ligands. Expert Opin. Ther. Pat. 1997, 7, 1447-1458.

25. Marot, C.; Chavatte, P.; Morin-Allory, L.; Guillaumet, G.; Viaud-Massuard, M.C.; Renard, P.; Lesieur, D.; Michel, A. Pharmacophoric Search and 3D-QSAR Comparative Molecular Field Analysis Studies on Agonists of Melatonin Sheep Receptors. J. Med. Chem. 1998, 41, 4453-4465.

26. Mésangeau, C.; Pérès, B.; Descamps-François, C.; Chavatte, P.; Audinot, V.; Coumailleau, S.; Boutin J.A.; Delagrange, P.; Bennejean, C.; Renard P.; et al. Design, synthesis and pharmacologicalevaluation of novelnaphthalenicderivatives as selective $\mathrm{MT}_{1}$ melatoninergic ligands. Bioorg. Med. Chem. 2010, 18, 3426-3436.

27. Descamps-François, C.; Yous, S.; Chavatte, P.; Audinot, V.; Bonnaud, A.; Boutin, J.A.; Delagrange, P.; Bennejean, C.; Renard, P.; Lesieur, D. Design and synthesis of naphthalenic dimers as selective $\mathrm{MT}_{1}$ melatoninergic ligands. J. Med. Chem. 2003, 46, 1127-1129.

28. Mésangeau, C.; Fraise, M.; Delagrange, P.; Caignard, D.H.; Boutin, J.A.; Berthelot, P.; Yous, S. Preparation and pharmacological evaluation of a novel series of 2-(phenylthio) benzo[b]thiophenes as selective $\mathrm{MT}_{2}$ receptor ligands. Eur. J. Med. Chem. 2011, 46, 1835-1840.

29. Durieux, S.; Chanu, A.; Bochu, C.; Audinot, V.; Coumailleau, S.; Boutin, J.A.; Delagrange, P.; Caignard, D.H.; Bennejean, C.; Renard, P.; et al. Design and synthesis of 3-phenyltetrahydronaphthalenic derivatives as new selective $\mathrm{MT}_{2}$ melatoninergic ligands. Part II. Bioorg. Med. Chem. 2009, 17, 2963-2974.

30. Poissonnier-Durieux, S.; Ettaoussi, M.; Pérès, B.; Boutin, J.A.; Audinot, V.; Bennejean, C.; Delagrange, P.; Caignard, D.H.; Renard, P.; Berthelot, P.; et al. Synthesis of 3-phenylnaphthalenic derivatives as new selective $\mathrm{MT}_{2}$ melatoninergic ligands. Bioorg. Med. Chem. 2008, 16, 8339-8348.

31. Yous, S.; Durieux-Poissonnier, S.; Lipka-Belloli, E.; Guelzim, H.; Bochu, C.; Audinot, V.; Boutin, J.A.; Delagrange, P.; Bennejean, C.; Renard, P.; et al. Design and synthesis of 3-phenyl tetrahydronaphthalenic derivatives as new selective $\mathrm{MT}_{2}$ melatoninergic ligands. Bioorg. Med. Chem. 2003, 11, 753-759.

32. Leclerc, V.; Ettaoussi, M.; Rami, M.; Farce, A.; Boutin, J.A.; Delagrange, P.; Caignard, D.H.; Renard, P.; Berthelot, P.; Yous, S. Design and synthesis of naphthalenic derivatives as new ligands at the melatoninbinding site $\mathrm{MT}_{3}$. Eur. J. Med. Chem. 2011, 46, 1622-1629.

33. Ettaoussi, M.; Péres, B.; Klupsch, F.; Delagrange, P.; Boutin, J.A.; Renard, P.; Caignard, D.H.; Chavatte, P.; Berthelot, P.; Lesieur, D.; et al. Design and synthesis of benzofuranic derivatives as new ligandsat the melatonin-binding site $M T_{3}$. Bioorg. Med. Chem. 2008, 16, 4954-4562. 
34. Leclerc, V.; Yous, S.; Delagrange, P.; Boutin, J.A.; Renard, P.; Lesieur, D. Synthesis of Nitroindole Derivatives with High Affinity and Selectivity for Melatoninergic Binding Sites MT3. J. Med. Chem. 2002, 45, 1853-1859.

35. Yous, S.; Andrieux, J.; Howell, H.E.; Morgan, P.J.; Renard, P.; Pfeiffer, B.; Lessieur, D.; Guardiola-Lemaitre, B. Novel naphthalenic ligands with high affinity for the melatonin receptor. J. Med. Chem. 1992, 35, 1484-1486.

36. Assogba, L.; Ahamada-Himidi, A.; Meddad-Bel Habich, N.; Aoun, D.; Boukli, L.; Massicot, F.; Mounier, C.M.; Huet, J.; Lamouri, A.; Ombetta, J.E.; et al. Inhibition ofsecretoryphospholipase A2. Design, synthesis and structure-activity relationship studies starting from 4-tetradecyloxybenzamidine to obtain specific inhibitors of group II sPLA2s. Eur. J. Med. Chem. 2005, 40, $850-861$.

37. Boukli, L.; Touaibia, M.; Meddad-Belhabich, N.; Djimdé, A.; Park, C.H.; Kim, J.J.; Yoon, J.H.; Lamouri, A.; Heymans, F. Design of new potent and selective secretory phospholipase A2 inhibitors. Part 5: Synthesis and biological activity of 1-alkyl-4-[4,5-dihydro-1,2,4-[4H]-oxadiazol5-one-3-ylmethylbenz-4'-yl(oyl)] piperazines. Bioorg. Med. Chem. 2008, 16, 1242-1253.

38. Lenda, F.; Guenoun, F.; Tazi, B.; Ben Larbi, N.; Allouchi, H.; Martinez, J.; Lamaty, F. Synthesis of New Tetrazole-Substituted Pyroaminoadipic and Pipecolic Acid Derivatives. Eur. J. Org. Chem. 2005, 326-333.

39. McKay, A.F.; Braun, R.O. Cyclizationsof $\beta$-Chloroethyl Substituted Amminocarbonic Acids. J. Org. Chem. 1951, 16, 1829-1832.

40. Depreux, P.; Lesieur, D.; Ait Mansour, H.; Morgan, P.; Howell, H.E.; Renard, P.; Caignard, D.H.; Pfeiffer, B.; Delagrange, P.; Guardiola, B.; et al. Synthesis and Structure-Activity Relationships of Novel Naphthalenic and Bioisosteric Related Amidic Derivatives as Melatonin Receptor Ligands. J. Med. Chem. 1994, 37, 3231-3239.

41. Mésangeau, C.; Yous, S.; Pérèz, B.; Lesieur, D.; Besson, T. Pictet-Spengler heterocyclizations via microwave-assisted degradation of DMSO. Tetrahedron Lett. 2005, 46, 2465-2468.

42. Dess, D.B.; Martin, J.C. Readily accessible 12-I-5 oxidant for the conversion of primary and secondary alcohols to aldehydes and ketones. J. Org. Chem. 1983, 48, 4155-4156.

43. Audinot, V.; Mailliet, F.; Lahaye-Brasseur, C.; Bonnaud, A.; Le Gall, A.; Amossé, C.; Dromaint, S.; Rodriguez, M.; Nagel, N.; Galizzi, J.P.; et al. New selective ligands of human cloned melatonin $\mathrm{MT}_{1}$ and $\mathrm{MT}_{2}$ receptors. Naunyn-Schmiedebergs Arch. Pharmacol. 2003, 36, 7553-7561.

Sample Availability: Samples of the compounds 5, 13, 14 and 15 are available from the authors.

(C) 2013 by the authors; licensee MDPI, Basel, Switzerland. This article is an open access article distributed under the terms and conditions of the Creative Commons Attribution license (http://creativecommons.org/licenses/by/3.0/). 